\title{
Emergence of bla TEM resistance gene in ESBL-producing Escherichia coli clinical isolates from Health facilities in Makurdi, Benue State Nigeria
}

\author{
Abba, P. O. ${ }^{1}$, Umeh, E. U. ${ }^{2}$, Gberikon, G. M. ${ }^{2}$ and Agbo, E. B. ${ }^{3}$ \\ ${ }^{1}$ Research scholar, Department of Medical Microbiology and Parasitology, Benue State University \\ Teaching Hospital, Makurdi, Benue State, Nigeria. \\ ${ }^{2}$ Professor, Department of Microbiology, Federal University of Agriculture, Makurdi, Benue State, Nigeria. \\ ${ }^{3}$ Professor, Department of Microbiology, Abubakar Tarfawa Balewa University, Bauchi, Bauchi State, \\ Nigeria.
}

\begin{abstract}
The emergence of extended-spectrum- $\beta$-lactamases (ESBLs)-producing Escherichia coli represents a serious clinical concern in healthcare. $\beta$-lactamases produced by these strains of E. coli render ineffective cephalosporins and other $\beta$-lactam antibiotics used to treat infections caused by Gram-negative bacteria. We determined the presence of ESBL in 400 clinical isolates of E. coli isolated from various clinical specimens (urine, stool, blood, sputum, throat and wound swabs) from 216 female and 184 male patients with mean age of $28.1 \pm 16.8$ years (age range: $2-71$ years), who were attending 6 selected health facilities in Makurdi, Benue State Nigeria. Antibiotic susceptibility test was carried out on the isolates using Kirby Bauer diffusion method. Presence of ESBLs was determined by the double disc synergy test (DDST). Specific primers were employed to characterize the ESBL gene using PCR. The isolates showed high level of resistance to all the antibiotics tested except mipenem. Highest resistance was to penicillin 392(98.0\%) followed by ceftriaxone 385(96.3\%). Out of the 400 isolates, 64 (16.0\%) tested positive for ESBLs by DDST method, while PCR technique confirmed 47(11.8\%) to harbour bla TEM genes. Isolates from blood specimens harboured highest percentage of ESBL genes 5(26.3\%) and also plasmid-mediated bla TEM genes 5(26.3\%), followed by wound swabs 9(17.3). The least percentage of plasmid-mediated bla TEM genes was carried by isolates from sputum specimens 1(8.3). Age group 45 to 58 years harboured the highest percentage of bla TEM genes 15(14.6\%), while female patients, 27(12.5\%) carried more bla TEM resistance genes than the male patients 20(10.9\%). A prevalence of $11.8 \%(n=47)$ of bla TEM resistance gene has been reported for the present study. In view of multidrug resistant ESBL-producing Escherichia coli bacteria circulating in the study location, prescription of antibiotics, especially cephalosporins should be based on laboratory results of antibiotic susceptibility tests that are carried out along with ESBL detection. Infection prevention and control strategies should be stepped up in the health facilities under study.
\end{abstract}

Key words: Antibiotic resistance, E. coli, ESBL, Makurdi, TEM.

\subsection{INTRODUCTION}

The joy that heralded the introduction of the third-generation cephalosporins into clinical practice in the early 1980s was shortlived because reports of plasmid-encoded $\beta$-lactamases capable of hydrolyzing the extended-spectrum cephalosporins began to emerge in 1983 [10]. The gene encoding the $\beta$-lactamase showed a mutation of a single nucleotide compared to the gene encoding SHV-1. Other $\beta$-lactamases were soon discovered which were closely related to TEM-1 and TEM-2, but which had the ability to confer resistance to the extended-spectrum cephalosporins [24], hence these new $\beta$-lactamases were coined extendedspectrum $\beta$-lactamases (ESBLs). Infectious diseases that became curable at the advent of antibiotics chemotherapy are again becoming killers of patients of all ages especially in developing countries [4].

Extended spectrum beta lactamases (ESBLs) which are mainly produced by Escherichia coli (E. coli) and K. pneumoniae render these antibiotics ineffective when used to treat infections caused by ESBL producing organisms, consequently increasing cost of therapy, morbidity and mortality [5]. Resistance to antibiotics affect all countries, but worse in developing countries because they 
have access to limited antibiotic options, engage in irrational antibiotic use, have poor drug quality and patronize inadequate health care systems [3]

Bla TEM resistance genes have been reported to confer resistance to ceftazidime, a third generation cephalosporin antibiotic [6]. The first report of bla TEM genes was made in Liverpool, England in 1982. Well over 100 TEM-type $\beta$-lactamases have been described, and majority are ESBLs. TEM-1 is able to hydrolyze ampicillin at a greater rate than carbenicillin, oxacillin, or cephalothin, and has negligible activity against extended-spectrum cephalosporins. It is inhibited by clavulanic acid.

Reports of bla TEM resistance genes circulating in health facilities abound. [12] reported a prevalence of 24.6\% in Ouagadougou, Burkina Faso. A study by [13] reported a prevalence of $87.1 \%$ bla TEM in Thailand, and a prevalence of $81.3 \%$ bla TEM genes was reported by [19] in South-West Nigeria. The burden of ESBL and bla TEM resistance organisms in clinical practice is poorly documented in Nigeria. Therefore, we determined the presence of ESBLs, and particularly bla TEM resistance genes, its distribution in clinical isolates of various clinical specimens and patterns of susceptibility to commonly used antimicrobial agents and $\beta$-lactam antibiotics in selected health facilities in Makurdi, North-Central Nigeria.

\subsection{MATERIALS AND METHODS}

This cross-sectional study was carried out in the department of Microbiology, Benue State University Teaching Hospital, Makurdi. The study was approved by the ethics committee of Benue State University Teaching Hospital Makurdi. A total of 400 Escherichia coli clinical isolates from blood, urine, stool, sputum, wound and throat swabs were collected from 6 selected health facilities in Makurdi, Benue State Nigeria, namely Benue State University Teaching Hospital, Federal Medical Centre, General hospital, Bishop Murray Medical Centre, Family support clinic and Primary Health Care Centre. Presumptive E. coli isolates from these specimens were identified by standard microbiological methods including colonial morphology, Gram reaction, biochemical-TSI, indole and motility.

Antibiotic susceptibility testing was performed by the Kirby Bauer disk diffusion method, using Mueller-Hinton agar, according to BSAC guidelines. The following agents were tested-Penicillin, ceftazidime, cefotaxime, ceftriaxone, Cefuroxime, ciprofloxacin, chloramphenicol, gentamycin and mipenem. ATCC strain 25922 E. coli was used as control strain and the breakpoint was determined by measurement of zone of inhibition.

The presence of ESBL was detected by placing a $30 \mu \mathrm{g}$ ceftazidime disk (the best indicator for TEM) on the left of each plate and a $30 \mu \mathrm{g}$ cefotaxime disk was placed on the right; an amoxicillin-clavulanic acid disk (AMC) (20/10 $\mu \mathrm{g})(\mathrm{Oxoid} \mathrm{Ltd}$ was placed in the centre between the other discs. The disks were placed $25 \mathrm{~mm}$ apart, centre-to-centre. Following overnight incubation in air at $37{ }^{0} \mathrm{C}$ ESBL production was inferred when the zone of inhibition around the ceftazidime and cefotaxime disks was expanded by $\geq 5 \mathrm{~mm}$ by the presence of clavulanic acid.

The DNA used for PCR molecular detection of bla TEM gene was extracted by the alkaline lysis method of Birnboim and Doly (1979). Specific primers for bla TEM, CTX and SHV were employed for the determination of bla TEM resistance genes. In multiplex PCR, $2 \mu \mathrm{L}$ whole cell lysate DNA of E. coli was used in $25 \mu \mathrm{L}$ PCR master mix and the specific primers. The PCR conditions were: Initial step of denaturation at $95^{\circ} \mathrm{C}$ for 5 minutes followed by 35 cycles of denaturation at $95^{\circ} \mathrm{C}$ for 1 minute, then annealing at $56^{\circ} \mathrm{C}$ for 1.5 minutes, extension at $95^{\circ} \mathrm{C}$ for 1 minute, and then final extension at $95^{\circ} \mathrm{C}$ for 10 minutes. The PCR products were separated electrophoretically using $1.5 \%$ agarose gel and stained with ethidium bromide. Bla TEM gene was identified by comparing the separated PCR products with the marker.

\subsection{STATISTICAL ANALYSIS.}

The data obtained were analyzed with SPSS version 20.0 applying Chi square at $95 \%$ to test degree of association.

\subsection{RESULTS.}

The isolates exhibited high level of resistance to all antimicrobial agents tested. Highest resistance was to penicillin (98.0\%, $\mathrm{n}=392)$, followed by ceftriaxone $(96.3 \% ; \mathrm{n}=385)$. The isolates were almost all susceptible to mipenem, a carbapenem (Table 1$)$. Out of 400 isolates tested, $64(16.0 \%)$ were positive for ESBL production. Isolates from blood specimens harboured the highest percentage 5(26.3\%), of ESBLs followed by wound specimen isolates 9(17.3\%). Highest percentage of bla TEM resistance genes were also harboured by blood specimen isolates (Table 3). Demographic data showed that higher number of isolates were gotten from female population $12.5 \%(n=27)$ compared with the male population $10.9 \%(n=20)$. Age group of 45 to $58(14.8 \%$; $n=8)$ years were prevalent (Table 5). General hospital Makurdi, $15.1 \%(\mathrm{n}=8)$ which is a secondary care hospital harboured higher percentage of plasmid-mediated bla TEM resistance genes followed by Benue State University Teaching Hospital, $13.6 \%(\mathrm{n}=$ 20) a tertiary care health facility. The primary Health Care centre $3.3 \%(\mathrm{n}=1)$ harboured the least percentage of bla TEM resistance genes (Table 6). 
International Journal of Advances in Scientific Research and Engineering (ijasre), Vol 5 (8), August-2019

Table 1: Susceptibility Profile of Isolated Escherichia coli to Antibiotics (N=400)

\begin{tabular}{llll}
\hline Antibiotics & $\begin{array}{l}\text { Disc } \\
\text { content }\end{array}$ & $\begin{array}{l}\text { Resistance } \\
(\%)\end{array}$ & $\begin{array}{l}\text { Susceptible } \\
(\%)\end{array}$ \\
\hline Penicillin & $10 \mu \mathrm{g}$ & $392(98.0)$ & $8(2.0)$ \\
Ceftriaxone & $30 \mu \mathrm{g}$ & $385(96.3)$ & $15(3.8)$ \\
Cefuroxime & $30 \mu \mathrm{g}$ & $376(94.0)$ & $24(6.0)$ \\
Cefotaxime & $30 \mu \mathrm{g}$ & $371(92.8)$ & $29(7.2)$ \\
Chloramphenicol & $30 \mu \mathrm{g}$ & $348(87.0)$ & $52(13.0)$ \\
Ciprofloxacin & $5 \mu \mathrm{g}$ & $336(84.0)$ & $64(16.0)$ \\
Ceftazidime & $30 \mu \mathrm{g}$ & $333(83.3)$ & $67(16.8)$ \\
Gentamycin & $10 \mu \mathrm{g}$ & $331(82.7)$ & $49(14.8)$ \\
Mipenem & $10 \mu \mathrm{g}$ & $02(0.5)$ & $398(99.5)$ \\
\hline
\end{tabular}

Table 2: Distribution of ESBL-producing Escherichia coli by Clinical Specimens

\begin{tabular}{llll}
\hline \multirow{2}{*}{ Specimen } & \multicolumn{2}{c}{ ESBL DETECTION } \\
& $\begin{array}{l}\text { Number positive } \\
(\%)\end{array}$ & $\begin{array}{l}\text { Number negative } \\
(\%)\end{array}$ & $\begin{array}{l}\text { Total number examined } \\
(\%)\end{array}$ \\
\hline Blood & $5(26.3)$ & $14(73.7)$ & $19(100)$ \\
Wound swabs & $9(17.3)$ & $43(82.7)$ & $52(100.0)$ \\
Urine & $33(16.5)$ & $167(83.5)$ & $200(100.0)$ \\
Stool & $16(14.5)$ & $94(85.5)$ & $110(100.0)$ \\
Sputum & $1(8.3)$ & $11(91.7)$ & $12(100.0)$ \\
Throat swabs & $0(0.0)$ & $7(100)$ & $7(100.0)$ \\
& & & $400(100.0)$ \\
Total & $64(16.0)$ & $336(84.0)$ & \\
\hline
\end{tabular}

$\chi^{2}=3.64 ; \mathrm{df}=5 ; \mathrm{p}=0.60$

Table 3: Distribution of Plasmid-mediated Bla TEM Gene By Specimen Types

\begin{tabular}{|c|c|c|c|}
\hline \multirow[b]{2}{*}{ Specimens } & \multicolumn{3}{|c|}{ Plasmid-mediated bla TEM } \\
\hline & Number negative $(\%)$ & Number positive (\%) & Total $(\%)$ \\
\hline Blood & $14(73.7)$ & $5(26.3)$ & $19(100.0)$ \\
\hline Wound swabs & $45(86.5)$ & $7(13.5)$ & $52(100.0)$ \\
\hline Urine & $178(89.0)$ & $22(11.0)$ & $200(100.0)$ \\
\hline Stool & $98(89.1)$ & $12(10.9)$ & $110(100.0)$ \\
\hline Sputum & $11(91.7)$ & $1(8.3)$ & $12(100.0)$ \\
\hline Throat swabs & $7(100.0)$ & $0(0.0)$ & $7(100.0)$ \\
\hline Total & $353(88.2)$ & $47(11.8)$ & $400(100.0)$ \\
\hline
\end{tabular}

$\chi^{2}=5.29, \mathrm{df}=5, \mathrm{p}=0.3$

Table 4: Distribution of Plasmid-mediated Bla TEM Gene by Age

\begin{tabular}{llll}
\hline & \multicolumn{2}{l}{ Plasmid-mediated bla TEM } & \\
Age $(\mathrm{yrs})$ & Number negative $(\%)$ & Number positive $(\%)$ & Total $(\%)$ \\
\hline$\leq 16$ & $95(88.8)$ & $12(11.2)$ & $107(100.0)$ \\
$17-30$ & $109(90.8)$ & $11(9.2)$ & $120(100.0)$ \\
$31-44$ & $88(85.4)$ & $15(14.6)$ & $103(100.0)$ \\
$45-58$ & $46(85.2)$ & $8(14.8)$ & $54(100.0)$ \\
$>59$ & $15(93.8)$ & $1(6.3)$ & $16(100.0)$ \\
Total & $353(88.2)$ & $47(11.8)$ & $400(100.0)$ \\
\hline
\end{tabular}


International Journal of Advances in Scientific Research and Engineering (ijasre), Vol 5 (8), August-2019

Table 5: Distribution of Plasmid-mediated bla TEM Gene by Sex.

\begin{tabular}{llll}
\hline Sex & Bla TEM & & \\
Number negative $(\%)$ & Number positive $(\%)$ & Total $(\%)$ \\
\hline Female & $189(87.5)$ & $27(12.5)$ & $216(100.0)$ \\
Male & $164(89.1)$ & $20(10.9)$ & $184(100.0)$ \\
Total & $353(88.2)$ & $47(11.8)$ & $400(100.0)$ \\
\hline
\end{tabular}

$\chi^{2}=0.255 ; \mathrm{df}=1 ; \mathrm{p}=0.614$

Table 6: Distribution of Plasmid-mediated Bla TEM Gene According to Health Facilities

\begin{tabular}{llll}
\hline & \multicolumn{2}{l}{ Plasmid-mediated Bla TEM } & \\
Health Facilities & Number negative $(\%)$ & Number positive $(\%)$ & Total $(\%)$ \\
\hline GH Makurdi & $45(84.9)$ & $8(15.1)$ & $53(100.0)$ \\
BSUTH Makurdi & $127(86.4)$ & $20(13.6)$ & $147(100.0)$ \\
FMC Makurdi & $88(88.0)$ & $12(12.0)$ & $100(100.0)$ \\
BMMC Makurdi & $27(90.0)$ & $3(10.0)$ & $30(100.0)$ \\
FSP Makurdi & $37(92.5)$ & $3(7.5)$ & $40(100.0)$ \\
PHC Makurdi & $29(96.7)$ & $1(3.3)$ & $30(100.0)$ \\
Total & $353(88.2)$ & $47(11.8)$ & $400(100.0)$ \\
\hline
\end{tabular}

$\chi^{2}=3.9 ; \mathrm{df}=5 ; \mathrm{p}=0.564$.

Key:

GH = General Hospital; BSUTH = Benue State University Teaching Hospital

FMC $=$ Federal Medical Centre BMMC $=$ Bishop Murray Medical Centre FSP $=$ Family Support Programme Clinic and $\mathrm{PHC}=$ Primary Health Care.

\subsection{DISCUSSION.}

Out of 400 isolates tested, $64(16.0 \%)$ produced extended spectrum $\beta$ - lactamases (ESBLs). Isolates that produce ESBLs are known to resist antimicrobial agents more than on- ESBL producers. This carriage of ESBLs is lower than some reports seen in some parts of Nigeria and other parts of the world: [19] reported 20.9\% $(n=28)$ in South West Nigeria, [23] reported 44.3\% in Benin- City Southern Nigeria, 36.8\% was reported for Kano State [18], 59.4\% in Enugu State [7], 66\% in Lagos [1], 41\% in Pakistan [8]. It is however, higher than 3.3\% reported from Gaza strip [2], 11.8\% from Macedonia [9]. Our finding is similar to the report of $18.6 \%$ by [20] from a neighboring Plateau State, Jos, North-Central Nigeria and $18.5 \%$ by [17] in India.

The susceptibility profiles of ESBL-producing Escherichia coli showed mipenem to be the most active antimicrobial agent. This is because mipenem is stable in the presence of ESBLs. Previous use of antimicrobial agents, especially cephalosporins and quinolones have been reported to be risk factors associated with emergence of ESBLs [22]. These antibiotics are the drug of choice for the treatment of infections by Gram-negative bacteria in Nigeria [19]. Sales and use of antibiotics is unregulated in Nigeria [14]. These might be the reason for the high prevalence of ESBL infections in Nigeria, especially in the present study location. Demographic data showed that female population carried a higher burden of ESBL infections than the male counterpart and the age group most affected is 45 to 58 years. This is in agreement with the report of [20] from Jos, North-Central Nigeria.

The PCR analysis yielded $11.8 \%(\mathrm{n}=47)$ of plasmid-mediated bla TEM variants. The prevalence of bla TEM resistance genes from this study is lower than the reports of other researchers from different parts of Nigeria and world: [21] reported a prevalence of 42.1\% ( $\mathrm{n}=48)$ from Ekiti State, Nigeria; [21], reported 32\% from Osun State, Nigeria where the highest percentage of bla TEM was recovered from sputum specimen (32\%) isolates and the next was from blood specimens (21.5\%). Maiduguri, Borno State in North-Eastern Nigeria had a prevalence of 31. 4\% (n =38) as reported by [18] to ceftazidime in his study. Though the prevalence of $11.8 \%$ for bla TEM in this study appear to be low compared to reports by other researchers; it is still important to consider it significant being the first report from the study location. With the free availability of antibiotics and unrestricted use, the prevalence will likely rise in the near future.

\subsection{CONCLUSION.}

The result from this study reported a relatively low occurrence of bla TEM resistance gene compared with reports from other parts of Nigeria and world. The emergence of ESBL- producing Escherichia coli poses a serious public health challenge, which will likely result in substantial limitations in the efficacy of therapeutic interventions. This study is the first report of the emergence of bla TEM gene in Makurdi, Benue State. There is need to establish screening strategies for early identification of patients that may be carriers of ESBL producing bacteria in the hospitals. Prescription of mipenem should be done with caution and carefully 
monitored, as it remains a viable option in a situation of overwhelming resistance of Enterobacteriaceae to other classes of routinely used antibiotics. This study has also shown the importance of infection, prevention and control measures to reduce the dissemination of antibiotic resistance within the hospital referral system in Makurdi, Benue State, Nigeria.

\section{Authors' contribution.}

P. O. Abba conceived, designed and executed the study; G. M. Gberikon and E. B. Agbo supervised data collection while E. U. Umeh analyzed the data and supervised manuscript writing. All authors read and approved the final manuscript.

\section{Conflict of interest.}

The authors declare none.

\section{Acknowledgments.}

The authors sincerely thank the laboratory staffs of Benue State University Teaching Hospital for their assistance during the research. We are also grateful to the nursing staff of the hospital for their cooperation during the process of sample collection.

\section{REFERENCES.}

1. E.O. Adenipekun, I. E. Aibinu and O.A. Dain, "Occurrence of Beta Lactamase Resistance among Isolates from Cancer Patients in Lagos, Nigeria" Researcher, 1, 2009, 1-6.

2. Z. Astal, F.A. Sharif, S.A. Abdallah, and M.I. Fahd, "Extended Spectrum Beta Lactamases in Escherichia coli Isolated from Community Acquired Urinary Tract Infections in the Gaza Strip, Palestine”. Annals of Saudi Medicine, 24, 2004, 55-57.

3. J.A Ayukekbong, M. Ntemgwa and A. N. Atabe. "The threat of antimicrobial resistance in developing countries: causes and control strategies", Antimicrob Resist Infect Control; 6(1) 2017, 47.

4. B. R. Blomberg, K. P. Jureen, B. S. Manji, D. S. Tamim, W. K. Mwakagile, M. Urassa, V. Fataki, M. G. Msangi, S. Y. Tellevik, and N. Langeland, "High rate of fatal cases of pediatric septicemia caused by gram-negative bacteria with extended-spectrum betalactamases in Dar es Salaam, Tanzania", J. Clin. Microbiol. 43: 2005, 745-749.

5. U. Chaudhary, and R. Aggarwal, "Extended Spectrum Beta-Lactamases (ESBLs). An Emerging Threat to Clinical Therapeutics", Indian Journal of Medical Microbiology, 22, 2004, 75-80.

6. S. K. Du Bois, M. S. Marriott and S. G. Amyes, "TEM- and SHV-derived extended-spectrum beta-lactamases: relationship between selection, structure and function", J. Antimicrob. Chemother. 35: 1995, 7-22

7. I.R Iroha, E.S. Amadi, A.E. Oji, A.C. Nwuzo and P.C. Ejike-Ugwu, "Detection of Plasmid Borne ESBL Enzymes from Blood and Urine Isolates of Gram Negative Bacteria from a University Teaching Hospital in Nigeria”, Current Research in Bacteriology, 3 , $2010,77-83$.

8. K. Jabeen, A. Zafar and R. Hasan, "Comparison of Double Disc and Combined Disc Method for the Detection of Extended Spectrum $\beta$ Lactamases in Enterobacteriaceae", Journal of Pakistan Medical Association, 53, 2003, 534-536.

9. Kaftandzhieva, V. Kotevska and G. Jankoska, "Extended Spectrum BetaLactamase among Multidrug Resistant Escherichia coli and Klebsiella pneumoniae in Children at a University Pediatric Clinic in Skopje”, Macedonian Journal of Medical Science, 2, 2009, 3641.

10. H. P. Knothe, V. Shah, M. Krcmery, Antal, and S. Mitsuhashi, "Transferable resistance to cefotaxime, cefoxitin, cefamandole and cefuroxime in clinical isolates of Klebsiella pneumoniae and Serratia marcescens", Infection 11: 1983, 315-317.

11. J. R. Knox, "Extended-spectrum and inhibitor-resistant TEM-type beta-lactamases: mutations, specificity, and three-dimensional structure", Antimicrobial. Agents Chemotherapy. 39: 1995, 2593-2601

12. D. S. Kpoda, A. Abraham, S. Marius, T. Oumar N. Guessennd, S. Aboubakar O. Lassana Sangare, S. Alfred Traore and M. Dosso, "Distribution of resistance genes encoding ESBLs in Enterobacteriaceae isolated from biological samples in health centers in Ouagadougou, Burkina Faso", BMC research notes. 11:471.

13. Nazemi, M. Yazdi, M. Mirinargasi, M. Jafarpour, and S. H Sharifi, "Genotypic versus Phenotypic methods to detect ExtendedSpectrum Beta-Lactamases (ESBLs) in Uropathogenic Escherichia coli”, Annals of Biological Research. 3 (5): 2012, 2454-2458

14. N. Okeke, A. Lamikaran and R. Edelman, "Socio-economic and behavioral factors leading to acquired bacterial resistance to antibiotics in developing countries", Emerging Infectious Diseases, 5 (1): 1999, 18 - 27.

15. R. Omoregie and N.O. Eghafona, "Urinary tract infection among asymptomatic HIV patients in Benin City. Nigeria", British Journal of Biomedical Science, 166 (4): 2009, 190 - 193.

16. Peymani, T. Naserpour-farivar, E. Zare and K. H. Azarhoosh, "Distribution of bla TEM, bla SHV, and bla CTX-M genes among ESBL-producing P. aeruginosa isolated from Qazvin and Tehran hospitals, Iran”, Journal of Preventive medicine and Hygiene; 58: 2017, E155-E160 
17. S.S. Tankhiwale, S.V. Jalgaonkar, S. Ahamad, and U. Hassani, "Evaluation of Extended Spectrum Beta Lactamase in Urinary Isolates", Indian Journal of Medical Research, 120: 2004, 53-556.

18. M. Yusha'u, M. Aliyu, S. Kumurya, and Suleiman, K. "Prevalence of Extended Spectrum Beta-Lactamases (Esbls) Among Enterobacteriaceae in Murtala Mohammed Specialist Hospital, Kano, Nigeria", Bayero Journal of Pure and Applied Sciences, 3, 2010, 169-172.

19. D.O. Ogbolu, O.A. Daini, A. Ogunledun, A.O. Alli and M.A Webber. "High levels of multidrug resistance in clinical isolates of Gram-negative pathogens from Nigeria". International Journal of Antimicrobial Agents, Elsevier; 37 (1): 2010 : pp.62.

20 K.I. Onyedibe, E.O Shobowale, M.O., Okolo, M.O. Iroezindu, T.O Afolaranmi, F.O Nwaokorie, S.O Opajobi, S.E Isa and Egah, D.Z. "Low Prevalence of Carbapenem Resistance in Clinical Isolates of Extended Spectrum Beta Lactamase (ESBL) Producing Escherichia coli in North Central, Nigeria". Advances in Infectious Diseases, 8, 2018: 109-120.

21 O. A. Olowe, O. Adewumi, G. Odewale,

O. Ojurongbe, and O. J. Adefioye "Phenotypic and Molecular Characterisation of Extended-Spectrum Beta-Lactamase Producing Escherichia coli Obtained from Animal Fecal Samples in Ado Ekiti, Nigeria" Journal of Environmental and Public Health, 2015: pp. 1-7

22. J. D. Knudsen and S. E. Andersen, "A multi-disciplinary intervention to reduce infections of ESBL- and AmpC-producing Gram negative bacteria at a university hospital" PLOS ONE; 9 (1) 2014: 86457.

23. H. O. Ogefere, P. A. Aigbiremwen, and Omoregie, R, "Extended-Spectrum BetaLactamase (ESBL)-Producing Gram-negative Isolates from Urine and Wound Specimens in a Tertiary Health Facility in Southern Nigeria". Tropical Journal of Pharmaceutical Research; 14 (6) 2015: 1089-1094

24. D. J. Sirot, R. Sirot, A. Labia, P. Morand, A. Courvalin, R. Darfeuille-Michaud, Perroux, and R. Cluzel, "Transferable resistance to third-generation cephalosporins in clinical isolates of Klebsiella pneumoniae: identification of CTX-1, a novel beta-lactamase" J. Antimicrob. Chemother. (20) 1987: 323-334. 